University of Wollongong

Research Online

Faculty of Engineering and Information

Faculty of Engineering and Information

Sciences - Papers: Part A

Sciences

$1-1-2013$

Deformation of coal fouled ballast stabilized with geogrid under cyclic load

Buddhima Indraratna

University of Wollongong, indra@uow.edu.au

Ngoc Trung Ngo

University of Wollongong, trung@uow.edu.au

Cholachat Rujikiatkamjorn

University of Wollongong, cholacha@uow.edu.au

Follow this and additional works at: https://ro.uow.edu.au/eispapers

Part of the Engineering Commons, and the Science and Technology Studies Commons

Research Online is the open access institutional repository for the University of Wollongong. For further information contact the UOW Library: research-pubs@uow.edu.au 


\title{
Deformation of coal fouled ballast stabilized with geogrid under cyclic load
}

\begin{abstract}
This paper presents the results of laboratory investigations into the deformation of coal fouled ballast stabilized with geogrid at various degrees of fouling. A novel track process simulation apparatus was used to simulate realistic rail track conditions subjected to cyclic loading, and the void contamination index $(\mathrm{VCl})$ was used to evaluate the level of ballast fouling. The experimental results show that coal fines act as a lubricant, causing grains of ballast to displace and rotate, and as a result, accelerate its deformation. However, coal fines also reduce ballast breakage because of a cushioning effect, that is, by reducing interparticle attrition. The inclusion of geogrid at the interface between the layer of ballast and subballast provides additional internal confinement and particle interlocking via geogrid apertures, which reduces deformation. A threshold value of $\mathrm{VCl} 540 \%$ is proposed to assist practitioners for conducting track maintenance. If the level of fouling exceeds this threshold, the geogrid reinforcement significantly decreases its effectiveness and the fouled ballast exhibits a premature dilation. Based on the experimental results, an equation incorporating the $\mathrm{VCl}$ was proposed to predict the deformation of fresh and fouled ballast. This equation improves track design and assists in favorable decision support for track maintenance. Additionally, the discrete element method (DEM) was also used to capture the deformation of fouled ballast subjected to cyclic loading, whereas the DEM results were compared with experimental observations.
\end{abstract}

Keywords

under, coal, load, ballast, cyclic, stabilized, geogrid, deformation, fouled

Disciplines

Engineering | Science and Technology Studies

\section{Publication Details}

Indraratna, B., Ngo, N. Trung. \& Rujikiatkamjorn, C. (2013). Deformation of coal fouled ballast stabilized with geogrid under cyclic load. Journal of Geotechnical and Geoenvironmental Engineering, 139 (8), 1275-1289. 


\title{
Deformation of Coal Fouled Ballast Stabilized with Geogrid under Cyclic Load
}

\author{
Buddhima Indraratna, Ph.D., F.ASCE ${ }^{1}$; Ngoc Trung $\mathrm{Ngo}^{2}$; and Cholachat Rujikiatkamjorn ${ }^{3}$
}

\begin{abstract}
This paper presents the results of laboratory investigations into the deformation of coal fouled ballast stabilized with geogrid at various degrees of fouling. A novel track process simulation apparatus was used to simulate realistic rail track conditions subjected to cyclic loading, and the void contamination index (VCI) was used to evaluate the level of ballast fouling. The experimental results show that coal fines act as a lubricant, causing grains of ballast to displace and rotate, and as a result, accelerate its deformation. However, coal fines also reduce ballast breakage because of a cushioning effect, that is, by reducing interparticle attrition. The inclusion of geogrid at the interface between the layer of ballast and subballast provides additional internal confinement and particle interlocking via geogrid apertures, which reduces deformation. A threshold value of $\mathrm{VCI}=40 \%$ is proposed to assist practitioners for conducting track maintenance. If the level of fouling exceeds this threshold, the geogrid reinforcement significantly decreases its effectiveness and the fouled ballast exhibits a premature dilation. Based on the experimental results, an equation incorporating the VCI was proposed to predict the deformation of fresh and fouled ballast. This equation improves track design and assists in favorable decision support for track maintenance. Additionally, the discrete element method (DEM) was also used to capture the deformation of fouled ballast subjected to cyclic loading, whereas the DEM results were compared with experimental observations. DOI: 10.1061/(ASCE)GT.1943-5606.0000864. (C) 2013 American Society of Civil Engineers.
\end{abstract}

CE Database subject headings: Discrete element; Railroad tracks; Railroad ballast; Dynamic loads; Geogrids; Cyclic loads.

Author keywords: Discrete elements; Railroad tracks; Dynamic loads; Geogrids.

\section{Introduction}

Ballast is a free-draining granular material that helps to transmit and distribute an induced cyclic load to the underlying subballast and subgrade at a reduced and acceptable level of stress (Selig and Waters 1994). Upon repeated train loading, ballast deteriorates and becomes fouled because of breakage and infiltration of external fine particles (e.g., coal fines, clay). Given typical Australian coal freight tracks, Feldman and Nissen (2002) stated that dry coal fines account for 70-95\% of the fouling materials in Australian tracks. Han and Selig (1997) investigated the effects of fouling on ballast settlement and demonstrated that settlement increases with an increasing degree of fouling. Budiono et al. (2004) argued that coal fines adversely affect the permanent settlement and strength of the track, because fouling decreases the resiliency and stiffness of the

\footnotetext{
${ }^{1}$ Professor of Civil Engineering and Research Director, Australian Research Council Centre of Excellence in Geotechnical Science and Engineering, Centre for Geomechanics and Railway Engineering, Faculty of Engineering, Univ. of Wollongong, Wollongong, NSW 2522, Australia (corresponding author). E-mail: indra@uow.edu.au

${ }^{2}$ Ph.D. Candidate, Australian Research Council Centre of Excellence in Geotechnical Science and Engineering, Centre for Geomechanics and Railway Engineering, Faculty of Engineering, Univ. of Wollongong, Wollongong City, NSW 2522, Australia.

${ }^{3}$ Associate Professor, Australian Research Council Centre of Excellence in Geotechnical Science and Engineering, Centre for Geomechanics and Railway Engineering, Faculty of Engineering, Univ. of Wollongong, Wollongong City, NSW 2522, Australia.

Note. This manuscript was submitted on January 18, 2012; approved on November 15, 2012; published online on November 19, 2012. Discussion period open until January 1, 2014; separate discussions must be submitted for individual papers. This paper is part of the Journal of Geotechnical and Geoenvironmental Engineering, Vol. 139, No. 8, August 1, 2013. CASCE, ISSN 1090-0241/2013/8-1275-1289/\$25.00.
}

ballast. Tutumluer et al. (2008), Dombrow et al. (2009), and Huang et al. (2009a) conducted direct shear tests of fresh and fouled ballast with different fouling materials at varying degrees of fouling, and showed that in view of reducing the shear strength, coal dust can be considered the worst fouling material.

Geogrid has been widely recognized as a useful method for stabilizing ballast, because it provides additional internal confining pressure and reinforcement, which (1) decreases maintenance costs and (2) enhances track serviceability (Bathurst and Raymond 1987; Göbel et al. 1994; Raymond 2002; Shin et al. 2002; Raymond and Ismail 2003; Brown et al. 2006, 2007; Fernandes et al. 2008; Qian et al. 2010; Indraratna et al. 2006, 2011a, b). When the geogrid is installed between the layers of ballast and subballast, it interacts with the surrounding grains to carry tensile loads imposed by the repeated train loadings by effectively interlocking between itself and the ballast. The effectiveness of geogrid primarily depends on its geometry, stiffness, cross-sectional shape of the rib, and strength at the junctions (Shukla and Yin 2006; Brown et al. 2007; Palmeira 2009).

When ballast is fouled, the interaction between the geogrid and ballast aggregates are expected to change substantially as fine particles accumulate within the pore matrix of the ballast assembly and reduce the mechanical interlocking and frictional resistance between the geogrid and ballast (Indraratna et al. 2011a). There has only been limited research carried out on coal fouled ballast reinforced with geogrid. Indraratna et al. (2011a) studied the interface of fouled ballast with geogrid subjected to direct shear loading, but this does not represent actual field conditions where the combination of geogrid and ballast undergoes repeated train loadings at low confining pressures. In this study, the novel track process simulation apparatus (TPSA) designed and built at the University of Wollongong was used to investigate the deformation of coal fouled ballast reinforced with geogrid while subjected to cyclic loading. 


\section{Materials Tested}

Samples of fresh ballast were collected from Bombo Quarry, New South Wales (NSW), Australia, then cleaned and sieved according to AS 2758.7 (Australia Standards 1996). The size and characteristics of the ballast and subballast are shown in Table 1 . To quantify ballast fouling, a novel method of capturing the specific gravities of different contaminants, as proposed earlier by Indraratna et al. (2011a), has been adopted as follows:

$$
\mathrm{VCI}=\frac{1+e_{f}}{e_{b}} \times \frac{G_{s b}}{G_{s f}} \times \frac{M_{f}}{M_{b}} \times 100
$$

where $e_{f}=$ void ratio of fouling material, $e_{b}=$ void ratio of fresh ballast, $G_{s b}=$ specific gravity of ballast, $G_{s f}=$ specific gravity of fouling material, $M_{f}=$ dry mass of fouling material, and $M_{b}=$ dry mass of fresh ballast. Selig and Waters (1994) defined the fouling index as a summation of percentage (by weight) passing the $4.75-\mathrm{mm}$ sieve (No. 4) and 0.075-mm sieve (No. 200). This parameter may lead to misinterpretation of the actual degree of fouling if the fouled material contains more than one type of material having considerably different specific gravities (e.g., coal and pulverized rock). In view of this, the void contamination index (VCI) is used herewith, which can capture the influence of different fouling materials having different specific gravities, as a modification to the traditional fouling indexes. The VCI has already been used by the Australian railway industry in the states of NSW and Queensland to quantify ballast fouling, in addition to the traditional methods, such as percentage void contamination proposed by Feldman and Nissen (2002) or the fouling index introduced by Selig and Waters (1994). Coal fines were provided by Queensland Rail and used as fouling material for VCIs of 10, 20, 40, and 70\%. The engineering characteristics of coal fines are presented in Table 2. Given the prolonged droughts in the state of Queensland and the usually prevailing hot climate most of the year in most states in Australia, the coal fouled tracks are often dry and not saturated as one may find in some North American tracks, for instance as tested by Tutumluer et al. (2008). Therefore, the coal fines tested were chosen to be relatively dry (moisture content $<4 \%$ ). It is agreed that plastic properties of coal dust can be affected if mixed with plastic clay in the field. However, in Australia, the vast majority of coal lines are mainly fouled by coal falling off the wagons during the passage of coal freight trains and there is insignificant mixing with clay. Apart from carbon-hydrogennitrogen studies, various minerals beneficiation methods, iron chromatography, atomic absorption, and X-ray diffraction tests conducted in the past have shown that coal fouling sampled from
Queensland tracks contains clay minerals less than 6-8\% that do not add significant plasticity to coal fouling. It is also true that the VCI in the field can vary with time because of ballast degradation and the rate of infiltration of coal fines, and that the fouling rate can also vary with location and time. The amount of coal fines was kept constant for each test to enable proper comparisons. It is expected that track inspection would be mandatory to ensure realistic evaluation of track performance. Biaxial geogrid manufactured from polypropylene, with 40- $\times 40$-mm-square apertures, was used. The properties of this geogrid are presented in Table 3 .

To represent field conditions, a 50-mm-thick layer of coarse sand compacted at $7 \%$ moisture content to a bulk unit weight of $19.5 \mathrm{kN} / \mathrm{m}^{3}$ was placed at the bottom of the apparatus to simulate a layer of subgrade. The 100-mm-thick layer of subballast above the subgrade consisted of a sand and gravel mixture compacted to a bulk unit weight of $20.8 \mathrm{kN} / \mathrm{m}^{3}$. Geogrid was placed on top of the subballast, followed by a $300-\mathrm{mm}$-thick layer of ballast compacted to field unit weight of $15.3 \mathrm{kN} / \mathrm{m}^{3}$. The initial void ratio of fresh ballast was 0.77 . Predetermined amounts of dry coal fines were added to the fresh ballast to simulate coal fouled ballast. The final void ratios of fouled ballast for $\mathrm{VCI}=40$ and $70 \%$ were 0.47 and 0.31 , respectively. To ease the recovery of ballast after each test, a nonwoven geotextile with a thickness of $2 \mathrm{~mm}$ was placed above the layer of subballast and beneath the geogrid to act as a separator such that the arrangement did not affect the interlock between the ballast particles and the geogrid. The characteristics of the geotextile are presented in Table 3. This type of geotextile is commonly used in rail tracks in Australia for the role of separation between ballast and subballast layers. The geotextile is very thin $(2 \mathrm{~mm})$ and placed loosely without tension, and there is no significant reinforcement effect from this. The particle-size distribution (PSD) of ballast is shown in Fig. 1, together with the PSD of subballast and coal fines.

\section{Track Process Simulation Apparatus}

To investigate the effects of geogrid and the influence of coal fines on the deformation and degradation of fresh and fouled ballast, a series of tests using the TPSA was conducted to simulate realistic track conditions. The novel track simulation apparatus was modified based on the original design by Indraratna and Salim (2003). Typically, for NSW ballast gradations, the initial stresses were kept constant around 6-7 $\mathrm{kPa}$ in the transverse direction (parallel to the sleeper) and about $10-12 \mathrm{kPa}$ along the longitudinal direction for which the lateral strains have to be kept as small as possible (i.e., plane strain). A lateral stress ratio of $0.5-0.7$ has been typical for maintaining plane strain for conventional axle loads. The lateral

Table 1. Grain Size Characteristics of Ballast and Subballast

\begin{tabular}{|c|c|c|c|c|c|c|c|c|c|}
\hline Test type & Particle shape & $d_{\max }(\mathrm{mm})$ & $d_{10}(\mathrm{~mm})$ & $d_{30}(\mathrm{~mm})$ & $d_{50}(\mathrm{~mm})$ & $d_{60}(\mathrm{~mm})$ & $C_{u}$ & $C_{c}$ & Size ratio \\
\hline Ballast & Highly angular & 53 & 16 & 28 & 35 & 39 & 2.4 & 1.3 & 11.3 \\
\hline Subballast & Angular to rounded & 19 & 0.23 & 0.45 & 0.61 & 0.8 & 3.5 & 1.1 & 31.6 \\
\hline
\end{tabular}

Note: $d_{\max }=$ maximum size ballast used; $d_{10}=$ diameter in millimeters at which $10 \%$ by weight of ballast passes through the sieve; $d_{30}, d_{50}, d_{60}=$ diameters in millimeters at which 30,50 , and $60 \%$ by weight of ballast passes through the sieve; $C_{u}=$ coefficient of uniform, defined by $C_{u}=d_{60} / d_{10} ; C_{c}=\operatorname{coefficient}$ of curvature, defined by $C_{c}=\left(d_{30}\right)^{2} / d_{10} / d_{60}$; size ratio $=$ the ratio of the width of the track process simulation apparatus $(600 \mathrm{~mm})$ to the mean diameter of maximum particle size based on at least two orthogonal directions.

Table 2. Engineering Properties of Coal Fines

\begin{tabular}{lcccccc}
\hline Material & Specific gravity & $\begin{array}{c}\text { Liquid limit } \\
\text { (percentage) }\end{array}$ & $\begin{array}{c}\text { Plastic limit } \\
\text { (percentage) }\end{array}$ & $\begin{array}{c}\text { Optimum moisture } \\
\text { content (percentage) }\end{array}$ & $\begin{array}{c}\text { Maximum dry } \\
\text { density }\left(\mathrm{kg} / \mathrm{m}^{3}\right)\end{array}$ & $\begin{array}{c}\text { Mean particle } \\
\text { size } d_{50}(\mathrm{~mm})\end{array}$ \\
\hline Coal fines & 1.28 & 91 & 50 & 35 & 874 \\
\hline
\end{tabular}


pressures were selected based on the lateral confinement provided by the weight of the crib and shoulder ballast, along with particle frictional interlock. Similar lateral pressures (and stress ratios) have been extensively used in previous studies, as reported by Indraratna and Salim (2003), and based on actual track measurements. Generally, the applied stress in the laboratory is controlled to vary within small limits in the longitudinal direction to ensure insignificant

Table 3. Physical and Technical Properties of Geogrid and Geotextile [reprinted from Indraratna et al. (2011a), with permission from Elsevier]

\begin{tabular}{lll}
\hline Geogrid physical characteristics & \multicolumn{1}{c}{ Data } \\
\hline Structure & Bioriented geogrid \\
Mesh type & Square apertures & \\
Standard color & Black & \\
Polymer type & Polypropylene & \\
Carbon black content & $2 \%$ & Biaxial geogrid \\
\hline Geogrid dimensional characteristics & $\mathrm{Unit}$ & 40 \\
\hline Aperture size & $\mathrm{mm}$ & 420 \\
Mass per unit area & $\mathrm{g} / \mathrm{m}^{2}$ & 77 \\
Percentage of open area & Percentage & Biaxial geogrid \\
\hline Geogrid technical characteristics & $\mathrm{Unit}$ & 10.5 \\
\hline Tensile strength at 2\% strain & $\mathrm{kN} / \mathrm{m}$ & 30 \\
Peak tensile strength & $\mathrm{kN} / \mathrm{m}$ & 11 \\
Yield point elongation & Pe11 & Data \\
\hline Geotextile physical characteristics & $\mathrm{Unit}$ & 140 \\
\hline Mass per unit area & $\mathrm{g} / \mathrm{m}^{2}$ & 2 \\
Thickness & $\mathrm{mm}$ & Polypropylene \\
Polymer type & - & Nonwoven \\
Geometry type & - & \\
\hline
\end{tabular}

strains (perpendicular to the sleeper). The lateral stress ratio is justified by field measurements from the Singleton and Bulli Tracks in NSW and also in agreement with large-scale laboratory tests conducted by Le Pen (2008). The schematic plan view and cross section of the TPSA are illustrated in Fig. 2. The TPSA can accommodate a ballast assembly $800-\mathrm{mm}$ long $\times 600$-mm wide $\times$ $600-\mathrm{mm}$ high. A system of hinges and ball bearings was regularly lubricated to minimize frictional resistance and enable the vertical walls to displace laterally with minimum friction. Eight steel pegs were placed at each of the sleeper/ballast and ballast/subballast interfaces to measure vertical settlement and help calculate the vertical strain of the ballast layer. A cyclic load was applied by a servohydraulic actuator and transmitted through the ballast by a wooden sleeper connected to a steel rail. An LVDT was connected to the load actuator to record its vertical movement. Confining pressures applied in two horizontal directions (perpendicular and parallel to the sleeper) were provided by hydraulic jacks connected with load cells to control the pressure applied during testing. Lateral movements of the four vertical walls were measured with 16 electronic potentiometers. The vertical stresses at the sleeper/ballast and ballast/subballast interfaces were measured by two pressure plates, as shown in Fig. 2. A typical harmonic cyclic load was estimated in accordance with Esveld (2001) and presented in Fig. 3. All tests were conducted at a frequency of $15 \mathrm{~Hz}$ with a maximum induced cyclic pressure of $420 \mathrm{kPa}$ and tested up to 500,000 load cycles. The frequency of $15 \mathrm{~Hz}$ was selected based on the freight lines operating in the proximity of $100 \mathrm{~km} / \mathrm{h}$ in NSW, Australia. In Australia, the axle loads vary from 25-30 t. In the field, a wheel load is transmitted both vertically (underneath sleeper) and laterally to adjacent sleepers. Atalar et al. (2001) reported that part of the wheel load is transmitted to the adjacent sleepers, and only 40-60\% of the wheel load is actually carried by the sleeper beneath the wheel. Therefore, in the test setup, the applied load of $20 \mathrm{t}$ over a single

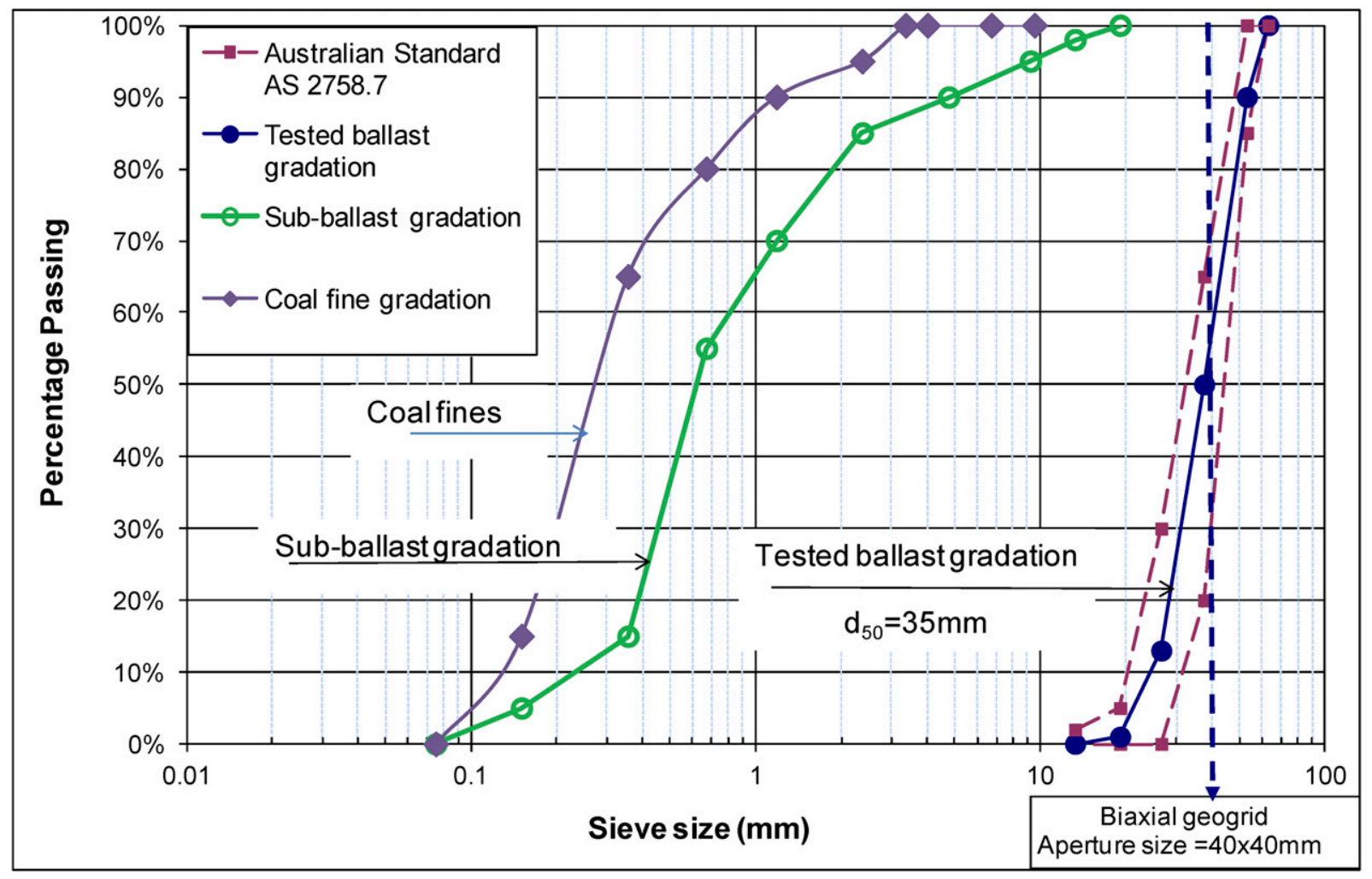

Fig. 1. Particle-size distribution of the ballast, subballast, and coal fines used 

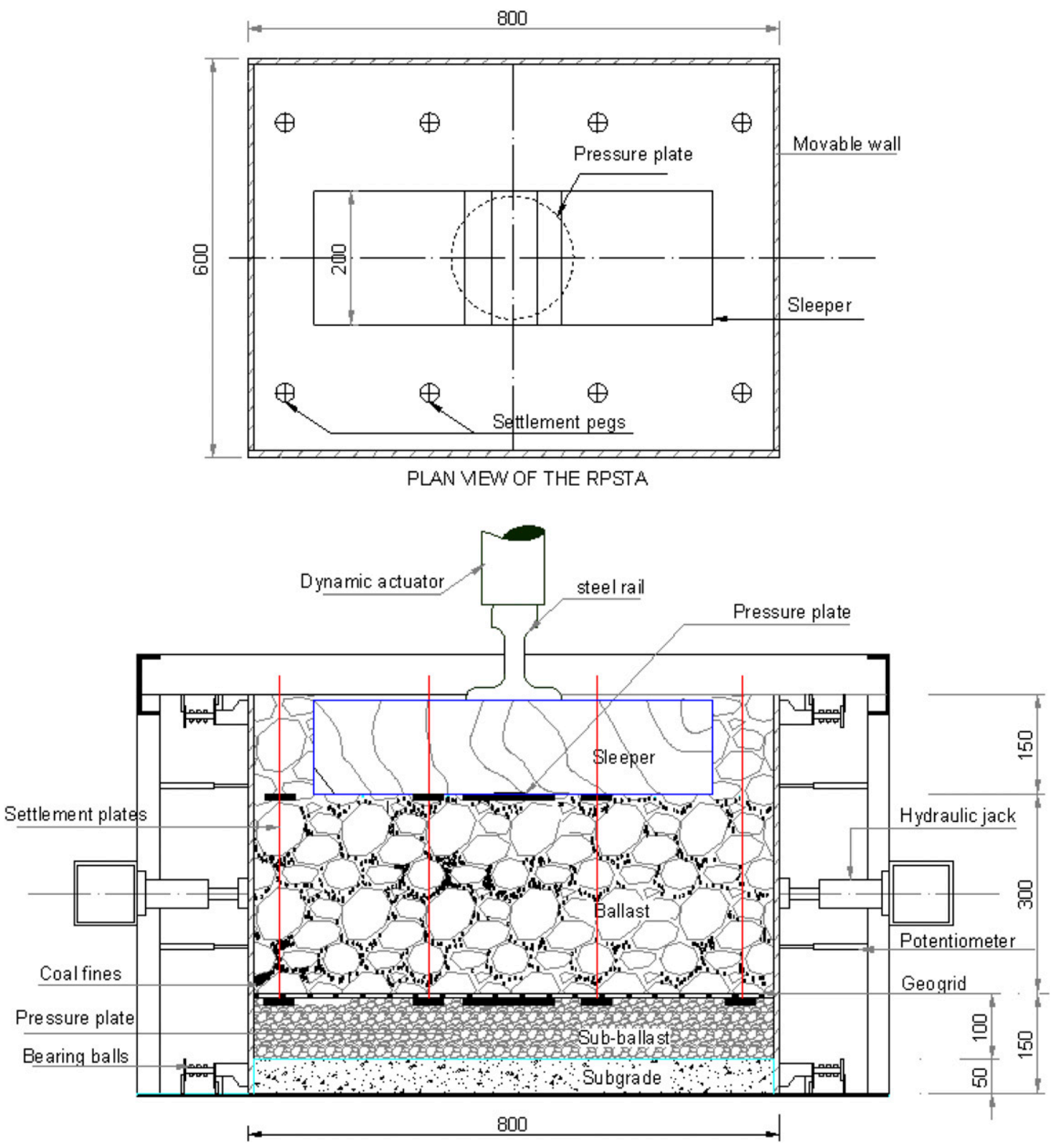

Fig. 2. Schematic plan view and cross section of the track process simulation testing apparatus (in millimeters)

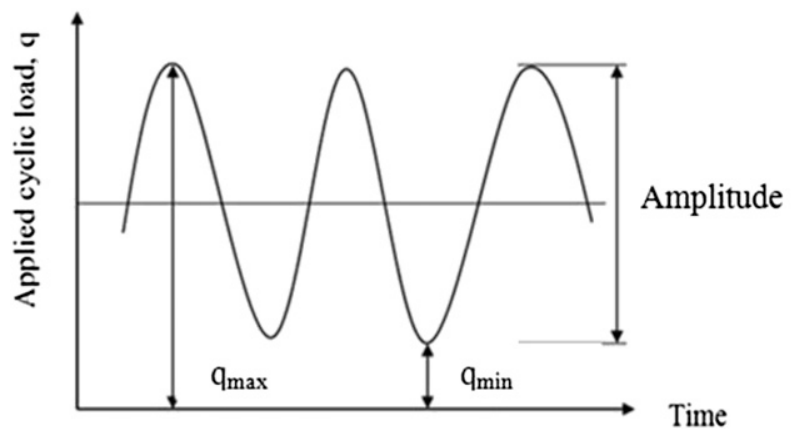

Applied cyclic load:

$$
\begin{aligned}
& \mathrm{q}_{\max }=420 \mathrm{kPa} \\
& \mathrm{q}_{\min }=45 \mathrm{kPa}
\end{aligned}
$$

Amplitude $=375 \mathrm{kPa}$

Frequency $=15 \mathrm{~Hz}$

Confining pressure:

$$
\begin{aligned}
& \sigma_{2}=10 \mathrm{kPa} \\
& \sigma_{3}=7 \mathrm{kPa}
\end{aligned}
$$

Fig. 3. Typical cyclic loading applied in the study 
timber sleeper $(650-\mathrm{mm}$ long and $220-\mathrm{mm}$ wide) is expected to generate a stress of $550-800 \mathrm{kPa}$ at the sleeper-ballast interface. The authors' current experimental measurements in the test rig show measurements around $420 \mathrm{kPa}$, which are even smaller. The field measurements made in several Australian case studies including the Bulli and Singleton Tracks have shown stresses just beneath the sleeper to be in the range of 350-500 kPa (Indraratna et al. 2011b). Therefore, the applied 20-t load in the experimental rig is justified, because it generates a realistic stress on the ballast. Every instrument was calibrated before connecting to an electronic data logger (DT800) and was controlled by a host computer supported by LabVIEW

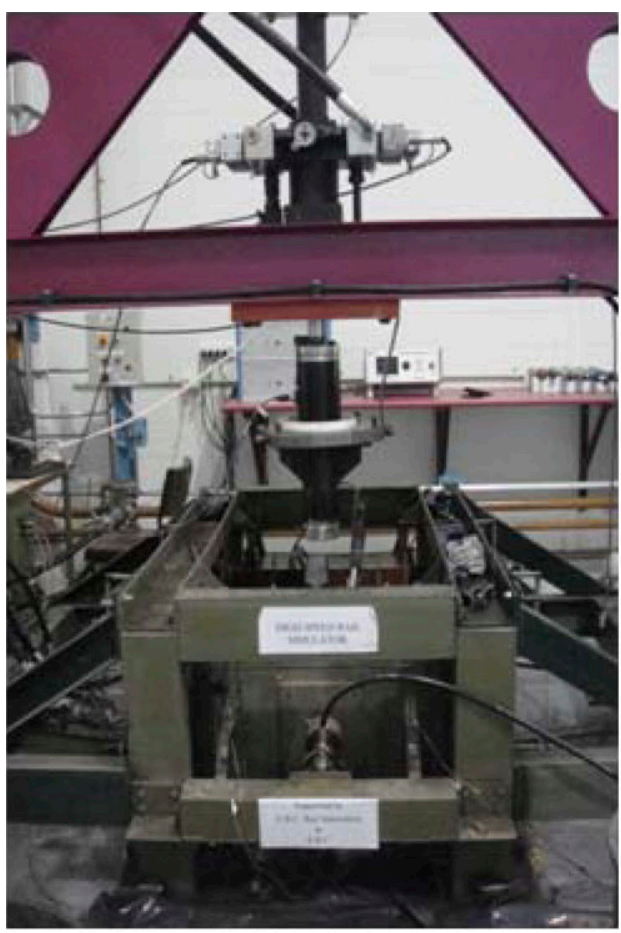

(a)

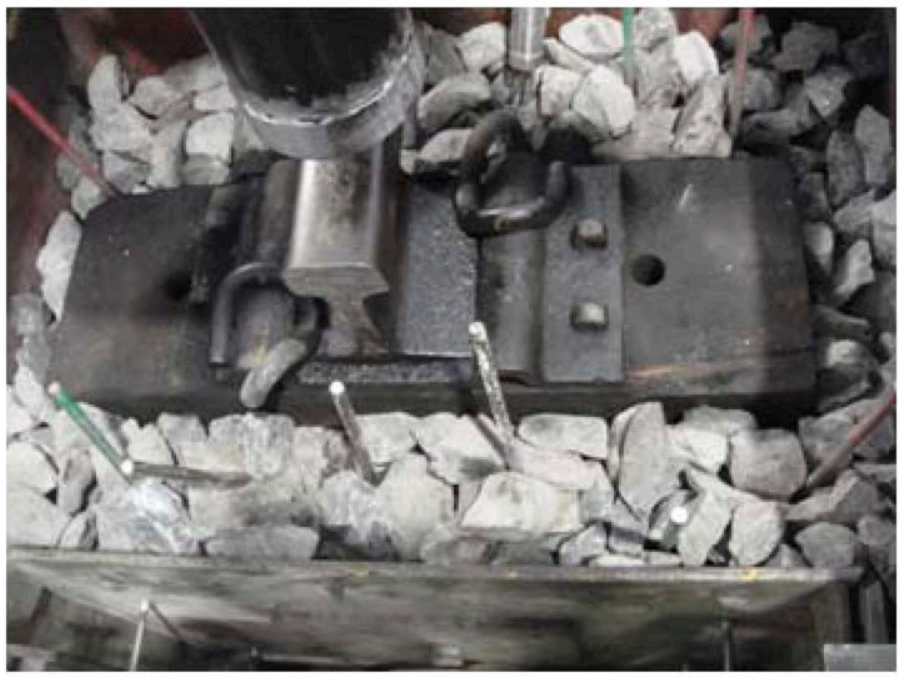

(d) software to accurately record vertical settlement, pressures, and the lateral displacement of associated walls at predetermined time intervals during the testing phase. Images of the typical components of the TPSA and coal fines are presented in Fig. 4.

\section{Specimen Preparation}

A total of 10 tests was conducted with and without geogrid, and with VCI varying from 0 to $70 \%$. The testing program and the amount of materials used for each test are presented in Table 4 . When the

(b)

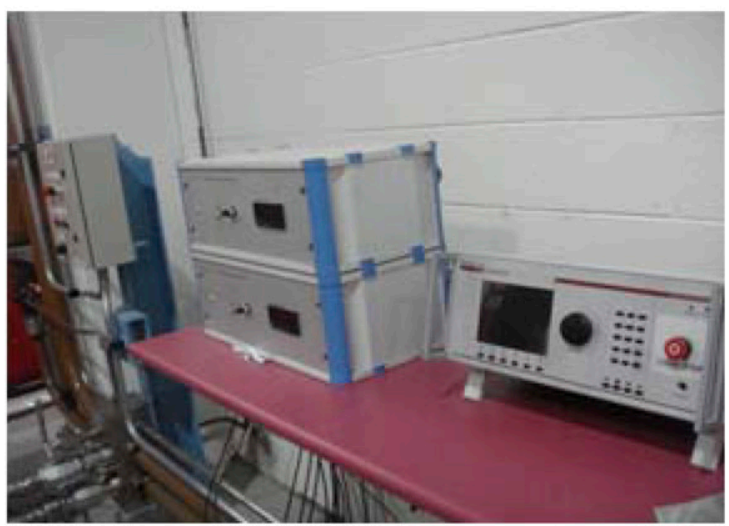

(c)
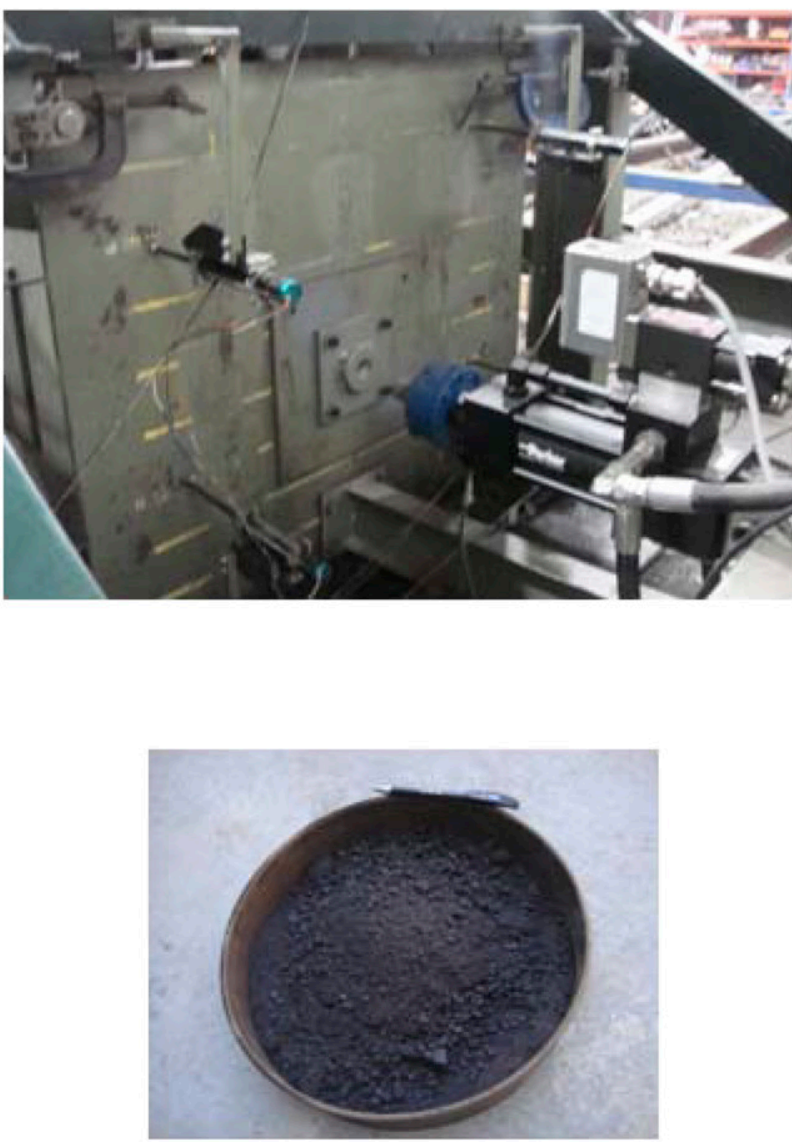

(e)

Fig. 4. Primary components of the track process simulation apparatus: (a) general view of the apparatus; (b) confining pressure control unit; (c) hydraulic jack, potentiometers, and clamps; (d) placement of the sleeper on the ballast layer; (e) coal fines 
Table 4. Testing Program and Amounts of Materials Used in Each Test

\begin{tabular}{|c|c|c|c|c|c|c|}
\hline $\begin{array}{l}\text { Void contamination } \\
\text { index (percentage) }\end{array}$ & $\begin{array}{c}\text { Fouling index } \\
\text { (percentage) }\end{array}$ & $\begin{array}{l}\text { Percentage void } \\
\text { contamination } \\
\text { (percentage) }\end{array}$ & $\begin{array}{l}\text { Without } \\
\text { geogrid }\end{array}$ & $\begin{array}{c}\text { With biaxial } \\
\text { geogrid } 40 \times 40 \mathrm{~mm}\end{array}$ & $\begin{array}{l}\text { Weight of } \\
\text { ballast (kg) }\end{array}$ & $\begin{array}{l}\text { Weight of coal } \\
\text { fines }(\mathrm{kg})\end{array}$ \\
\hline 0 & 0 & 0 & $X$ & $X$ & 220 & 0 \\
\hline 10 & 2.3 & 6.5 & $X$ & $X$ & 220 & 5.20 \\
\hline 20 & 4.5 & 12.9 & $X$ & $X$ & 220 & 10.40 \\
\hline 40 & 8.6 & 25.8 & $X$ & $X$ & 220 & 20.80 \\
\hline 70 & 14.1 & 45.2 & $X$ & $X$ & 220 & 36.40 \\
\hline
\end{tabular}

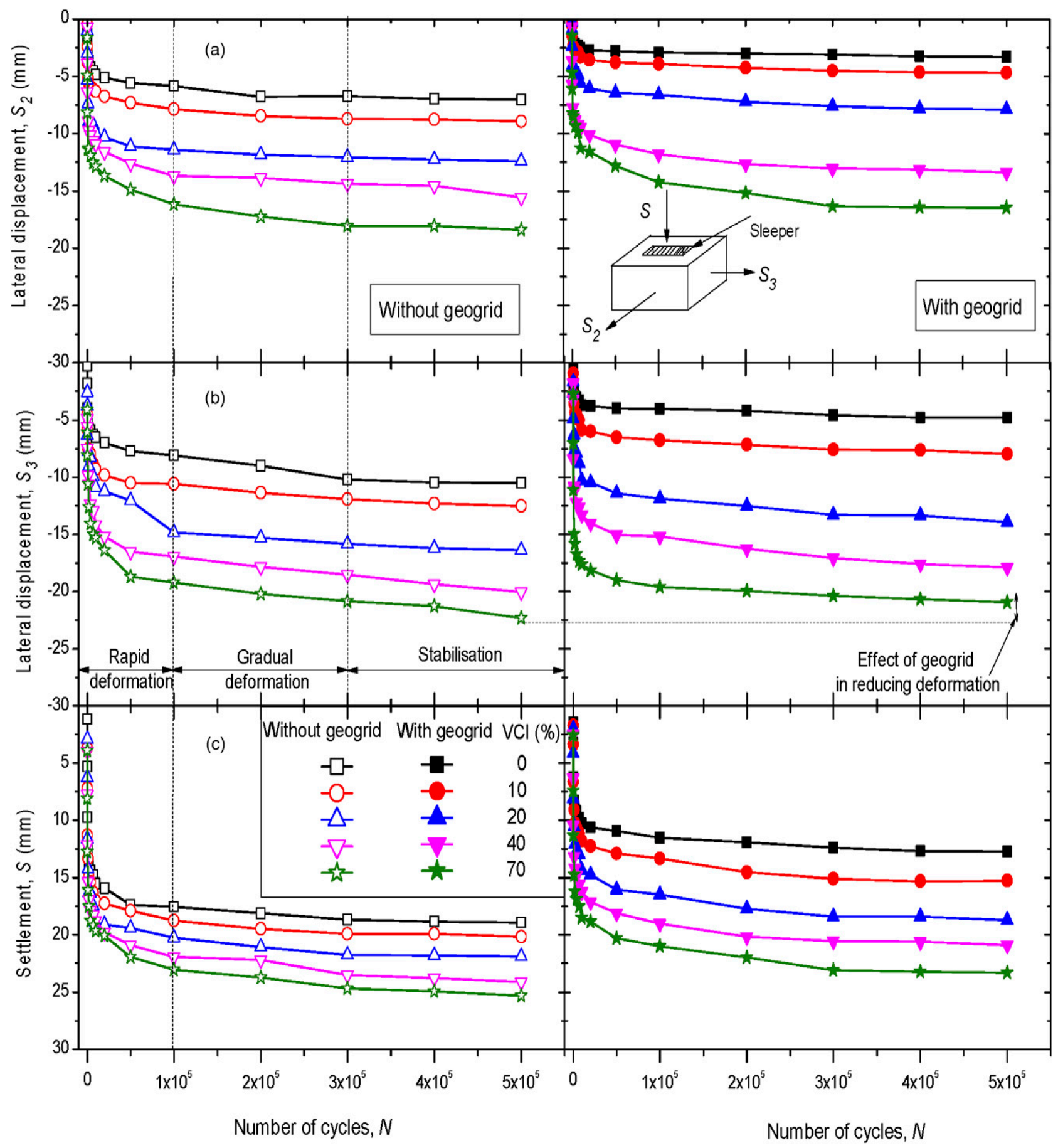

Fig. 5. Variations in the deformation of fresh and fouled ballast with and without geogrid with varying VCIs: (a) lateral displacement $\left(S_{2}\right.$, perpendicular to the sleeper); (b) lateral displacement $\left(S_{3}\right.$, parallel to the sleeper); (c) settlement $(S)$ 
samples were being compacted, the side walls of the TPSA were clamped to prevent any deformation. Layers of subgrade and subballast were prepared using a vibratory compactor to desired unit weights, as mentioned previously. A pressure plate, settlement pegs, and the geogrid were then placed onto the layer of subballast. The sample of ballast was divided and compacted into five equal sublayers $(60-\mathrm{mm}$ thick). Each layer was compacted with a hand vibrator until the simulated field unit weight (typically at $15.3 \mathrm{kN} / \mathrm{m}^{3}$ ) was achieved. A rubber pad was placed beneath the vibrator to prevent particle breakage during compaction. A total of five sublayers of fresh ballast $(60 \mathrm{~mm}$ for each sublayer) was compacted, and then the coal dust was blown through the ballast voids to realistically simulate the field conditions where the coal fines fall off wagons and then infiltrate the ballast bed. This technique also prevents the ballast structure from being disturbed. The subsequent layers of ballast and coal fines were similarly compacted until the ballast attained its final height of $300 \mathrm{~mm}$. A wooden sleeper was then placed on top of the ballast and connected to a hydraulic actuator via a steel ram. Eight settlement pegs were then placed on top of the ballast, and then more ballast was placed onto the top level of the sleeper to represent the crib and shoulder ballast.

After the assembly had been prepared, the clamps were removed and lateral pressures $\left(\sigma_{2}=10 \mathrm{kPa}\right.$ and $\left.\sigma_{3}=7 \mathrm{kPa}\right)$ corresponding to confining pressures typically provided by the crib and shoulder ballast in the real track were applied [Fig. 4(c)]. An initial vertical pressure of $45 \mathrm{kPa}$ was then applied to stabilize the sleeper-ballast assembly and to serve as a reference for all lateral displacement and settlement readings. A cyclic load was then applied through a servohydraulic actuator to a maximum pressure of $420 \mathrm{kPa}$ at a frequency of $15 \mathrm{~Hz}$. These loading characteristics induced an approximately mean contact stress of $233 \mathrm{kPa}$ onto the sleeper and ballast, which represents a $20 \mathrm{t}$ per axle train loading traveling at approximately $80 \mathrm{~km} / \mathrm{h}$ under typical Australian track conditions. A total of half a million load cycles was applied in each test, but was interrupted at specific cycles $(1,10,100,1,000,2,000,4,000,7,000,15,000$, $30,000,50,000,100,000,200,000,300,000,400,000,500,000)$ to take readings of settlement pegs and to capture the resilience of ballast material at the end of these cycles. Therefore, the rest periods have been captured when selecting these specific cycles, and test interruptions have been conducted accordingly. Lateral displacements and vertical stresses were automatically recorded by an automated data logger.

\section{Test Results and Discussion}

\section{Lateral Deformation of Fresh and Fouled Ballast}

The lateral deformation of fresh and fouled ballast, in both horizontal directions, with and without geogrid (perpendicular and parallel to the sleeper), is presented in Figs. 5( $a$ and b). Here, the geogrid significantly decreased the lateral displacement of fresh and fouled ballast. Indeed, when particles of ballast were compacted over the geogrid, they partially penetrated and projected through the apertures and created a strong mechanical interlock between the geogrid and now restrained ballast. This interlocking effect enabled the geogrid to act as a nonhorizontal displacement boundary that confined and restrained the ballast from free movement, which in turn decreased its deformation. This supports the previous studies conducted by Konietzky et al. (2004), and McDowell et al. (2006), where the DEM was used to investigate the interaction between the geogrid and ballast. They concluded that the geogrid provides a significant interlocking effect by creating a stiffened zone on each side. During cyclic loading application and associated vibrations, ballast particles can rotate and move, and the initial void

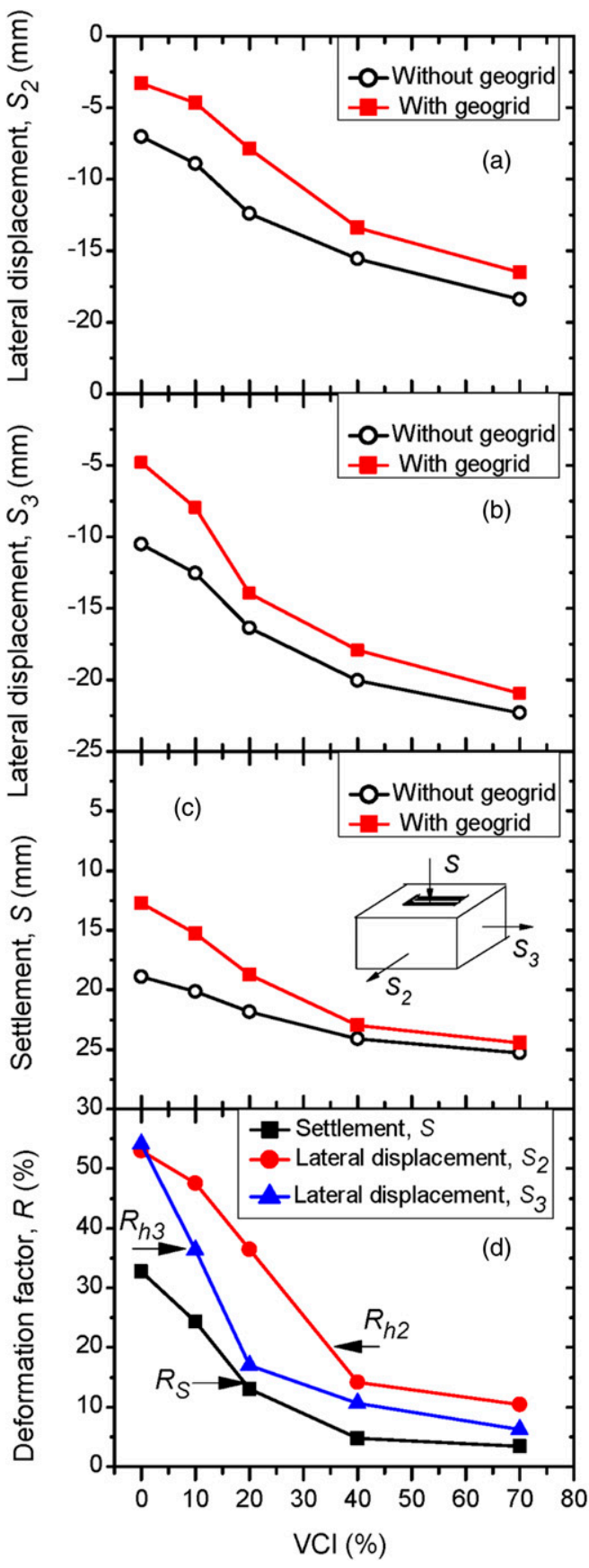

Fig. 6. Variations of final deformation of fresh and fouled ballast with and without geogrid with varying VCIs: (a) lateral displacement $S_{2}$; (b) lateral displacement $S_{3}$; (c) settlement $S$; (d) ballast deformation factor, $R$

arrangement and the contact distribution would change accordingly. An increased VCI results in a significantly larger lateral displacement, because when fouling increases, it is highly likely that fouling material (e.g., fines coal dust) coats the ballast grain surfaces (process sometimes referred to as armoring) and intrudes between the contact points, thereby offering a lubricating effect, which in turn helps the particles of the ballast slide and roll over each other. However, the ability of the geogrid to reduce lateral displacement also diminishes when the VCI increases, because when the ballast layer was carefully removed after the test, the coal fines had accumulated in the apertures of the geogrids, decreasing the effective size of the geogrid aperture. 


\section{Vertical Settlements of Fresh and Fouled Ballast}

The average accumulated vertical settlement of fresh and fouled ballast at selected load cycles was measured using settlement pegs and an LVDT. Fig. 5(c) presents the settlement of fresh and fouled ballast assemblies compared with those of geogrid-reinforced ballast at various VCIs. Generally, the settlement of geogrid-reinforced ballast was less than the unreinforced assembly for any given VCI, although fresh ballast reinforced with geogrid showed the least settlement. As expected, an increasing level of fouling causes more ballast deformation. All the samples had the same initial rapid settlement up to 100,000 cycles, followed by gradually increasing settlement within 300,000 cycles, and then remained relatively stable to the end (500,000 cycles). This clearly indicated that ballast undergoes considerable rearrangement and densification during initial load cycles, but after attaining a threshold compression, any subsequent loading would resist further settlement, and instead promote dilation when the ballast specimen could not compress further $\left(\varepsilon_{2}+\varepsilon_{3}>\varepsilon_{1}\right)$. This increased settlement was also attributed to coal fines acting as a lubricant, as previously mentioned.
The measured data are best interpreted by Figs. 6(a-d), which plot the final values of deformation and the relative deformation factor at $N=500,000$ with varying VCIs. The relative deformation factor $(R)$ can be defined as follows:

Vertical settlement $(\%): R_{s}=\frac{S_{(\text {unreinforced })}-S_{(\text {reinforced })}}{S_{(\text {unreinforced })}} \times 100$

Lateral deformation $(\%): R_{h 2}=\frac{S_{2 \text { (unreinforced) }}-S_{2(\text { reinforced })}}{S_{2(\text { unreinforced })}}$ $\times 100$

Lateral deformation $(\%): R_{h 3}=\frac{S_{3 \text { (unreinforced) }}-S_{3(\text { reinforced })}}{S_{3 \text { (unreinforced })}}$ $\times 100$

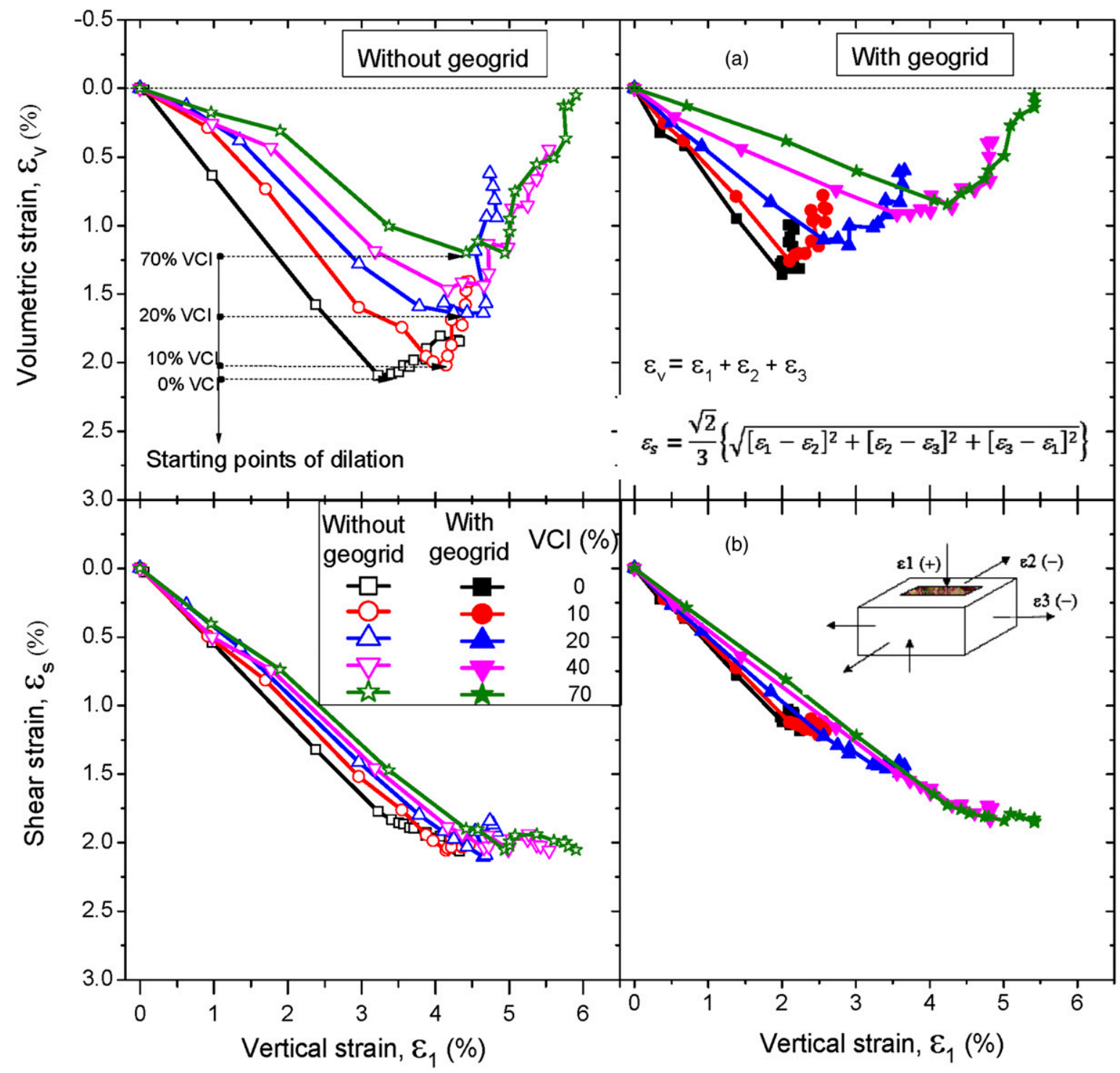

Fig. 7. Variations of average volumetric strain and shear strain versus average vertical strain of fresh and fouled ballast with and without geogrid for various VCIs 

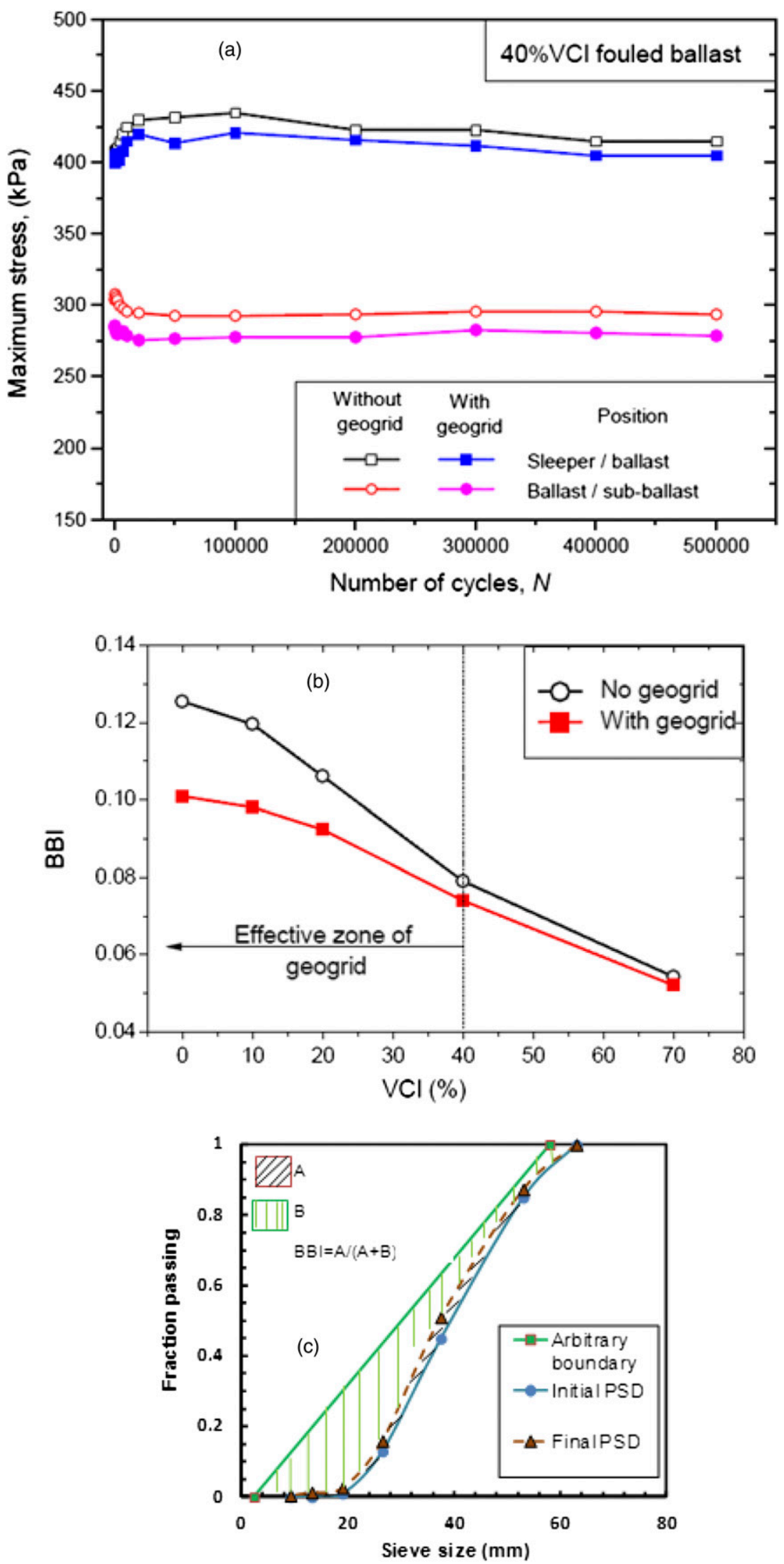

Fig. 8. (a) Variations of maximum vertical stresses; (b) ballast breakage index of ballast assemblies with and without geogrid; (c) particle-size distributions before and after testing 


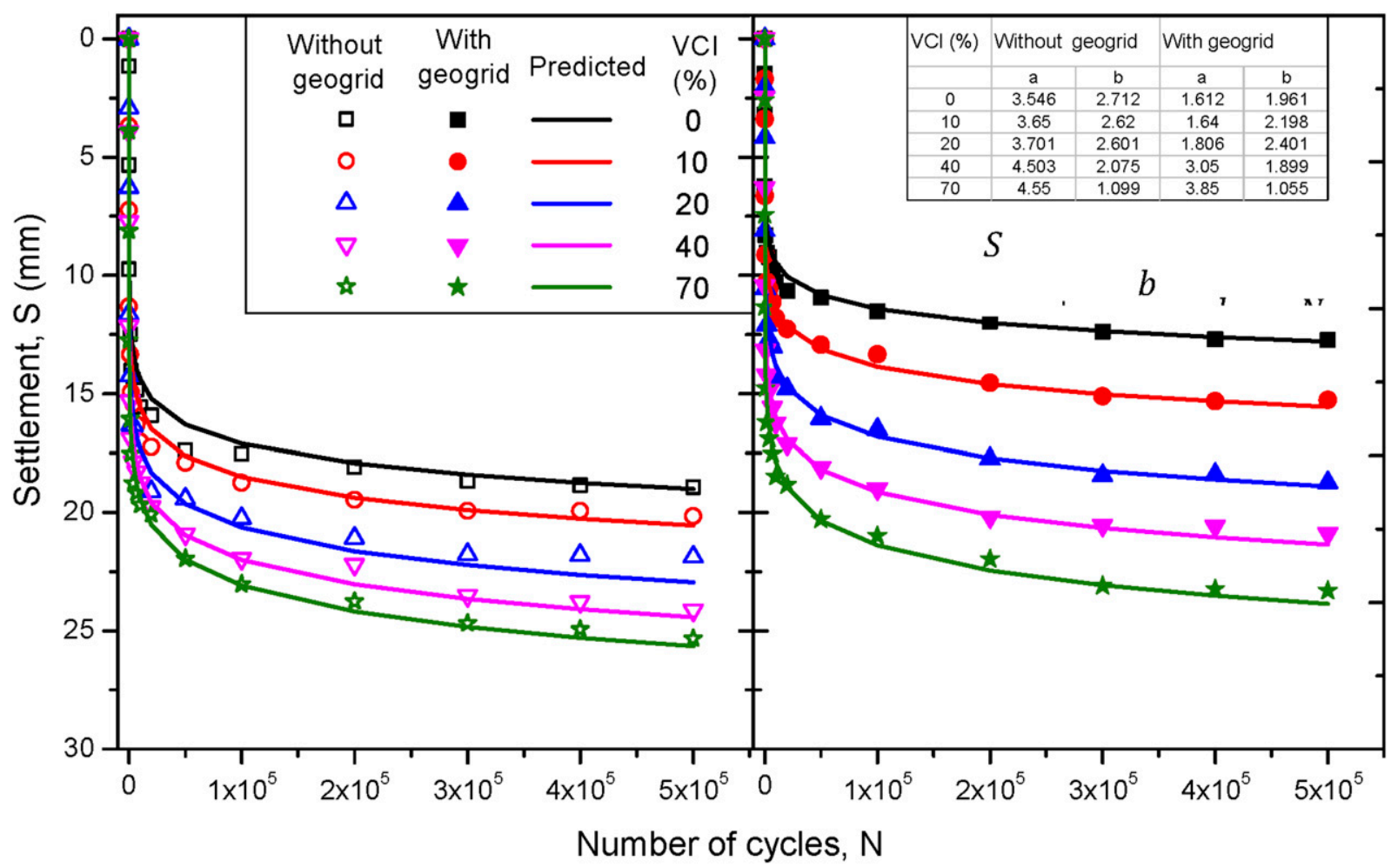

Fig. 9. Comparisons of ballast settlement at varying VCIs with/without geogrid inclusion measured experimentally and predicted

The beneficial effect of the geogrid on reducing ballast deformation, as expected, is clearly reflected by the values of $R$ presented in Fig. $6(d)$. The observed benefit of the geogrid decreased with an increase of the VCI and became marginal when VCI $>40 \%$. Geogrid can reduce the deformation of fresh ballast (approximately 52 and $32 \%$ reduction for lateral and vertical deformation, respectively), and this value significantly decreases with an increase of the VCI (approximately 12 and 5\% reduction for lateral and vertical deformation, respectively, for $\mathrm{VCI}=40 \%$ ). As the $\mathrm{VCI}$ increased beyond $40 \%$ or so, the subsequent decrease in the value of $R$ became gradual compared with fresh ballast and fouled ballast with the $\mathrm{VCI}=10$ and $20 \%$. This observation was supported by the fact that at $\mathrm{VCI}=40 \%$ and beyond, coal fines filled the ballast voids and geogrid apertures. This phenomenon inhibits interparticle friction and prevents the ballast particles from effectively interlocking with the geogrid. Based on this data, it is possible to propose a threshold value of $\mathrm{VCI}=40 \%$, where the effect of geogrid becomes marginal and track maintenance becomes imperative.

\section{Average Volumetric and Shear-Strain Responses}

The average vertical strain of the ballast layer $\left(\varepsilon_{1}\right)_{\text {avg }}$ was calculated based on the differences between settlement at the sleeper/ballast and ballast/subballast interfaces, as measured by the settlement pegs. The average lateral strains perpendicular and parallel to the sleeper $\left[\left(\varepsilon_{2}\right)_{\mathrm{avg}},\left(\varepsilon_{3}\right)_{\mathrm{avg}}\right]$ were then calculated using the lateral displacement of the four vertical walls, as measured by the potentiometers. The average volumetric strain $\left(\varepsilon_{v}\right)_{\text {avg }}$ and shear strain $\left(\varepsilon_{s}\right)_{\text {avg }}$ can be calculated as follows (Timoshenko and Goodier 1970):

$$
\left(\varepsilon_{v}\right)_{\mathrm{avg}}=\left(\varepsilon_{1}\right)_{\mathrm{avg}}+\left(\varepsilon_{2}\right)_{\mathrm{avg}}+\left(\varepsilon_{3}\right)_{\mathrm{avg}}
$$

Table 5. Micromechanical Parameters of Ballast Particles and Walls Applied in Discrete Element Method Simulation

\begin{tabular}{ll}
\hline Micromechanical parameters & \multicolumn{1}{c}{ Values } \\
\hline Radius of particle $(\mathrm{m})$ & $1.8 \times 10^{-3}-16 \times 10^{-3}$ \\
Interparticle coefficient of friction & 0.80 \\
Particle normal and shear contact stiffness $(\mathrm{N} / \mathrm{m})$ & $3.58 \times 10^{8}$ \\
Normal and shear stiffness of wall $(\mathrm{N} / \mathrm{m})$ & $3 \times 10^{7}$ \\
Parallel bond normal and shear stiffness $(\mathrm{N} / \mathrm{m})$ & $6.25 \times 10^{10}$ \\
Parallel bond normal and shear strength $\left(\mathrm{N} / \mathrm{m}^{2}\right)$ & $5.78 \times 10^{6}$ \\
Parallel bond radius multiplier & 0.5 \\
Particle density $\left(\mathrm{kg} / \mathrm{m}^{3}\right)$ & 2,700 \\
\hline
\end{tabular}

Table 6. Micromechanical Parameters of Coal Fines and Number of Coal Fine Particles Generated in Discrete Element Method

\begin{tabular}{lcl}
\hline $\begin{array}{l}\text { Void contamination } \\
\text { index (percentage) }\end{array}$ & $\begin{array}{c}\text { Number of } \\
\text { coal particles }\end{array}$ & \multicolumn{1}{c}{ Microproperties of coal fines } \\
\hline 0 & 0 & $\begin{array}{l}\text { Particle normal and shear contact } \\
\text { stiffness: } k_{n}=k_{s}=1.27 \times 10^{4}(\mathrm{~N} / \mathrm{m})\end{array}$ \\
10 & 1,095 & $\begin{array}{l}\text { Interparticle friction coefficient, } \\
\mu=0.2\end{array}$ \\
20 & 2,190 & $\begin{array}{l}\text { Radius of particle: } 1.5(\mathrm{~mm}) \\
\text { Particle density }=1,280 \mathrm{~kg} / \mathrm{m}^{3}\end{array}$ \\
70 & 4,380 & \\
\hline 0 & 7,665 & \\
\hline
\end{tabular}

$$
\begin{aligned}
& \left(\varepsilon_{s}\right)_{\mathrm{avg}}=\frac{\sqrt{2}}{3} \\
& \times\left\{\sqrt{\left[\left(\varepsilon_{1}\right)_{\mathrm{avg}}-\left(\varepsilon_{2}\right)_{\mathrm{avg}}\right]^{2}+\left[\left(\varepsilon_{2}\right)_{\mathrm{avg}}-\left(\varepsilon_{3}\right)_{\mathrm{avg}}\right]^{2}+\left[\left(\varepsilon_{3}\right)_{\mathrm{avg}}-\left(\varepsilon_{1}\right)_{\mathrm{avg}}\right]^{2}}\right\}
\end{aligned}
$$


Fig. 7(a) shows the volumetric strain plotted against the average vertical strain. Generally, all the specimens showed a significant volumetric compression at the initial vertical strain, which then progressed to a threshold compression followed by dilation at subsequent loading cycles. With the volumetric strain, the fouled ballast with the highest VCI started dilating earlier than the specimens with a lower VCI. Whereas the $70 \%$ VCI fouled ballast showed dilation occurring at approximately $\left(\varepsilon_{v}\right)_{\mathrm{avg}}=1.2 \%$, the $20 \% \mathrm{VCI}$ fouled ballast and fresh ballast started dilating at $\left(\varepsilon_{v}\right)_{\mathrm{avg}}=1.7 \%$ and $\left(\varepsilon_{v}\right)_{\mathrm{avg}}=2.2 \%$, respectively. This premature dilation of fouled ballast may be considered as one of the important signs associated with track instability (Indraratna et al. 2011b). Fouled specimens reinforced with geogrid showed a similar trend of volumetric behavior compared with unreinforced ballast, except that the maximum values of $\left(\varepsilon_{v}\right)_{\text {avg }}$ for ballast reinforced with geogrid were somewhat smaller than those for unreinforced ballast. These differences were primarily attributed to additional interlocking provided by the geogrid, which confined and restrained the ballast from moving freely.

The average shear-strain response $\left(\varepsilon_{s}\right)_{\text {avg }}$ versus average vertical strain $\left(\varepsilon_{1}\right)_{\text {avg }}$ for fresh and fouled ballast is also presented in Fig. 7(b). The data show that the geogrid reduced the average shear strain of fresh and fouled ballast assemblies for any given VCI. The shear strain for all the specimens increased significantly at the beginning, but it gradually increased with a subsequent increase in the vertical strain.

\section{Maximum Stresses and Ballast Degradation}

Fig. 8(a) presents a comparison of the maximum stresses at the sleeper/ballast and ballast/subballast interfaces of fouled ballast with $\mathrm{VCI}=40 \%$. As expected, geogrid placed between the layers of ballast and subballast resulted in a slight decrease in maximum stress compared with the unreinforced ballast assembly. At the initial 50,000 cycles, the measured maximum vertical stress at sleeper/ballast increased, whereas the maximum stress at the ballast/subballast interface decreased. The lower stress at the sleeper/ballast interface within the initial 30,000 cycles can be attributed to interparticle contacts that may not have been fully developed. Subsequent load cycles would increase the interparticle contacts through densification.

Under cyclic loading, the ballast deteriorates because of the breakage of sharp corners and attrition of asperities, apart from particles splitting at high contact pressure (Indraratna et al. 2005; Lackenby et al. 2007). The volume of ballast broken can be determined by sieving it before and after every test and then quantifying the differences of the PSDs. Indraratna et al. (2005) proposed a ballast breakage index (BBI) for quantifying ballast breakage. According to ballast samples obtained at Bulli (NSW) prior to track maintenance, the BBI was in the range of $8-11 \%$, which is similar to the values obtained in the laboratory. The BBI of fresh and fouled ballast with and without geogrid is presented in Fig. 8(b). The particle-size distributions before and after testing for fresh ballast are plotted in Fig. 8(c) to demonstrate how the VCI can be calculated. Ballast reinforced with geogrid showed a significantly reduced breakage compared with an unreinforced specimen of ballast. The reduction of the BBI associated with the geogrid is primarily reflected by the reduced maximum stresses presented in Fig. 8(a), which would also imply reduced interparticle contact stresses. The ability of geogrid to reduce the breakage of fresh ballast is very notable, but as the VCI increased beyond $40 \%$ or so, the ability of the geogrid to reduce degradation became marginal. The BBI also decreased considerably with an increase of the VCI for both reinforced and unreinforced assemblies of ballast. This was primarily attributed to the coal fines occupying the ballast voids and acting as a cushioning layer, leading to diminished interparticle contact stresses and associated breakage.

\section{Proposed Deformation Model of Fouled Ballast}

Various researchers have attempted to model the settlement of fresh ballast empirically (Shenton 1975; Raymond and Bathurst 1994;

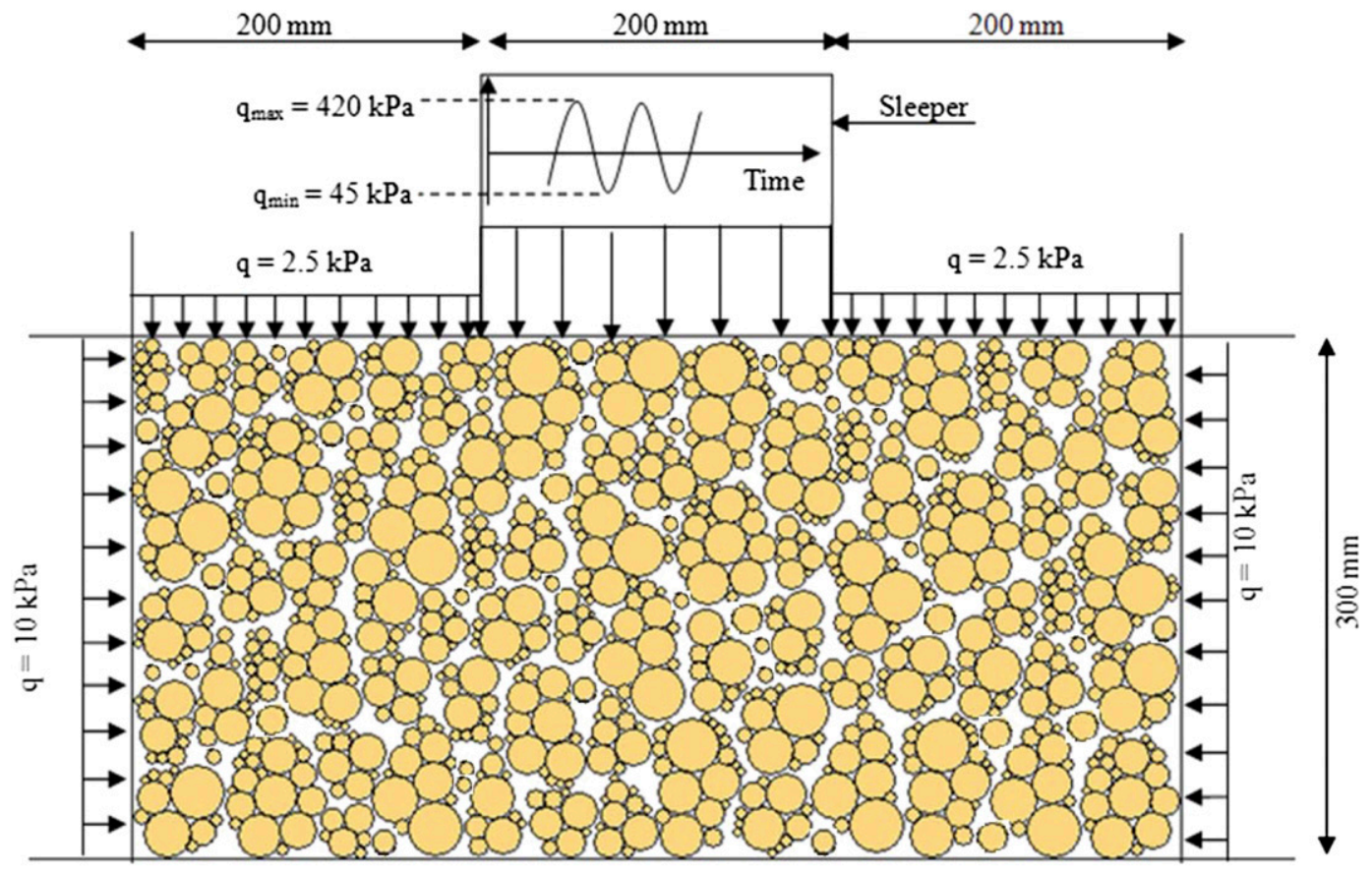

$600 \mathrm{~mm}$

Fig. 10. Discrete element method boundary conditions and applied cyclic load to simulate fresh ballast 
Indraratna et al. 2002). However, their proposed empirical equations were primarily applied to fresh ballast, and they were unable to consider the rate at which ballast deteriorates and fouls during cyclic loading. Therefore, based on the data measured experimentally, this study is a first attempt to propose an empirical equation to predict track settlement, $(S)$, considering the degree of fouling, (VCI), as defined by

$$
S=a+\frac{b}{1-\mathrm{VCI}} \log _{10} N
$$

where $S=$ settlement, $\mathrm{VCI}=$ void contamination index $(0 \leq \mathrm{VCI}<1)$, $a$ and $b=$ empirical coefficients depending on the VCI, and $N=$ number of load cycles.
A comparison of ballast settlement with and without geogrid at varying VCIs, compared with the results based on Eq. (7), is shown in Fig. 9. The predicted settlements agree with data measured experimentally. The empirical values $a$ and $b$ at varying VCIs were also tabulated in Fig. 9, which are applicable for the test setup condition and the commonest ballast type (latite basalt) and the most common fouling material (coal) in Australian freight tracks. Parameters $a$ and $b$ can vary with the subgrade characteristics including thickness and stiffness, which can be different from the conditions of the laboratory test setup, fouling materials, moisture content, and ballast gradation. From a practical perspective, the proposed Eq. (7) can help practicing engineers predict track settlement and simultaneously consider ballast fouling.

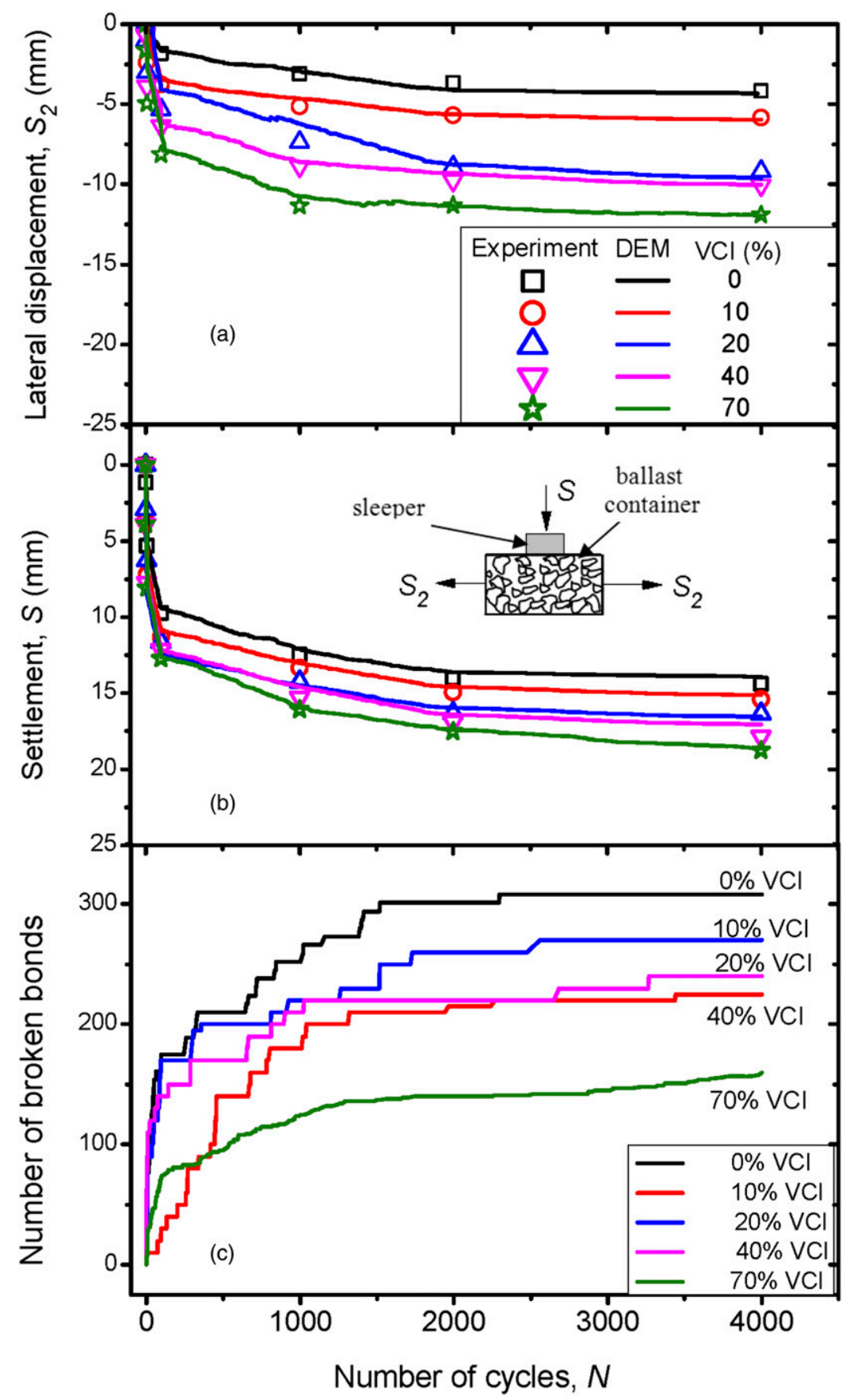

Fig. 11. Variations of lateral displacement, settlement, and number of broken bonds with load cycles obtained from discrete element method simulations compared with data measured experimentally 


\section{Numerical Simulation Using the Discrete Element Method}

The discrete element method (DEM) introduced by Cundall and Strack (1979) has been used to model the behavior of ballast (Lim and McDowell 2005; Lobo-Guerrero and Vallejo 2005; Lu and McDowell 2006, 2008; Hossain et al. 2007; Huang et al. 2009b; Indraratna et al. 2010). The DEM enables the discrete nature of grains to be modeled by providing an insight into microscale factors, such as particle shape, interparticle movements, and contact force chains developed among particles that cannot be otherwise determined. $\mathrm{Lu}$ and McDowell (2010) used the DEM to simulate fresh ballast subjected to 100 load cycles and presented that DEM simulation can capture ballast behavior and results are comparable with 500,000 cycles in the laboratory testing. Indraratna et al. (2010) simulated fresh ballast in the DEM subjected to 1,000 load cycles to capture behavior of fresh ballast in view of contact for chain and particle breakage mechanisms. The use of the DEM to model fouled ballast under cyclic loading is very limited to date. Huang et al. (2009b) and Huang and Tutumluer (2011) simulated fouled ballast by reducing the interparticle coefficient of friction under direct shear loading, but they did not examine the effect of different levels of fouling.

The realistic size and shape of grains of ballast and the procedures to simulate them in PFC2D version 3.10 (Itasca 2003) were adopted from Indraratna et al. (2010), where clusters of circular-bonded particles were used to model irregularly shaped grains of ballast. The degradation of bonds within a cluster was considered to represent ballast breakage. The micromechanical parameters of ballast grains and walls used in the DEM are presented in Table 5. Descriptions of similar DEM simulations have been given by Indraratna et al.
(2010). Coal fines were simulated in the DEM by injecting predetermined amounts of $1.5-\mathrm{mm}$-radius particles into the voids to represent a specific VCI (Table 6). The DEM boundary conditions to simulate fresh ballast, including a cyclic load applied onto a sleeper, the lateral confining pressure applied onto vertical walls, and the vertical pressure induced by the weight of the crib ballast filling the gap between the vertical walls and sleeper, are illustrated in Fig. 10. The lateral and vertical pressures of 10 and $2.5 \mathrm{kPa}$, respectively, were kept constant by adjusting the position and velocity of the vertical and top walls using a numerical servocontrol mechanism (Itasca Consulting Group 2003). Subroutines developed by Indraratna et al. (2010) were then used to apply a controlled stress, cyclic simulation similar to the aforementioned laboratory testing. Because of the calculation time, cyclic tests for fresh and fouled ballast at $\mathrm{VCI}=10,20,40$, and $70 \%$ were simulated to a number of load cycles, $N=4,000$, where most of the ballast deformation and degradation took place as observed in the laboratory. The objectives of the DEM study were to model the discrete nature of grains and to provide an insight into microscale factors, such as particle shape, interparticle movements, and contact force chains developed among particles that cannot be otherwise determined, especially during the initial cycles. The current DEM models based on PFC2D have obvious limitations, where a large number of cycles, such as $N=40,000$, cannot be simulated, even with the supercomputer used by the authors for this analysis. It will be interesting to compare the DEM with laboratory data at a large number of cycles. At this stage, it is beyond the scope of the current DEM analysis because of this computational limitation.

Lateral displacements and vertical settlements of the ballast assemblies were determined by monitoring the movement of

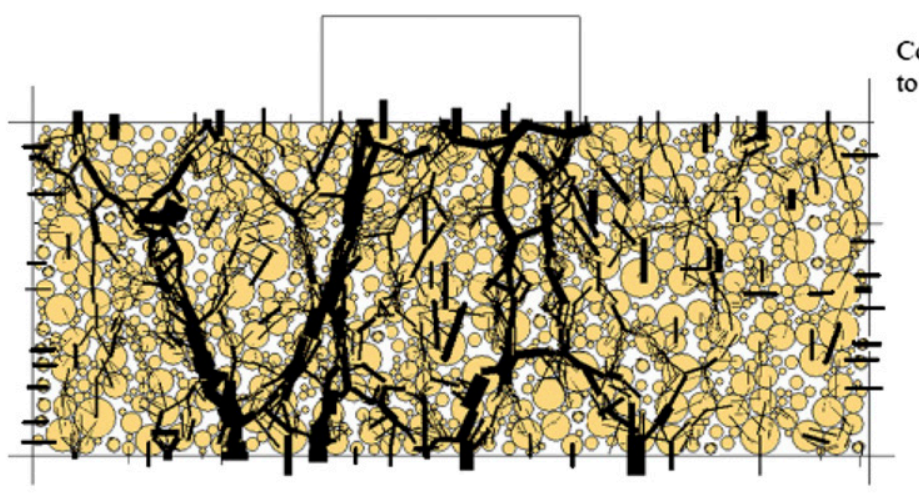

Contact forces transferred Ballast grains to coal fines

(a) Fresh ballast
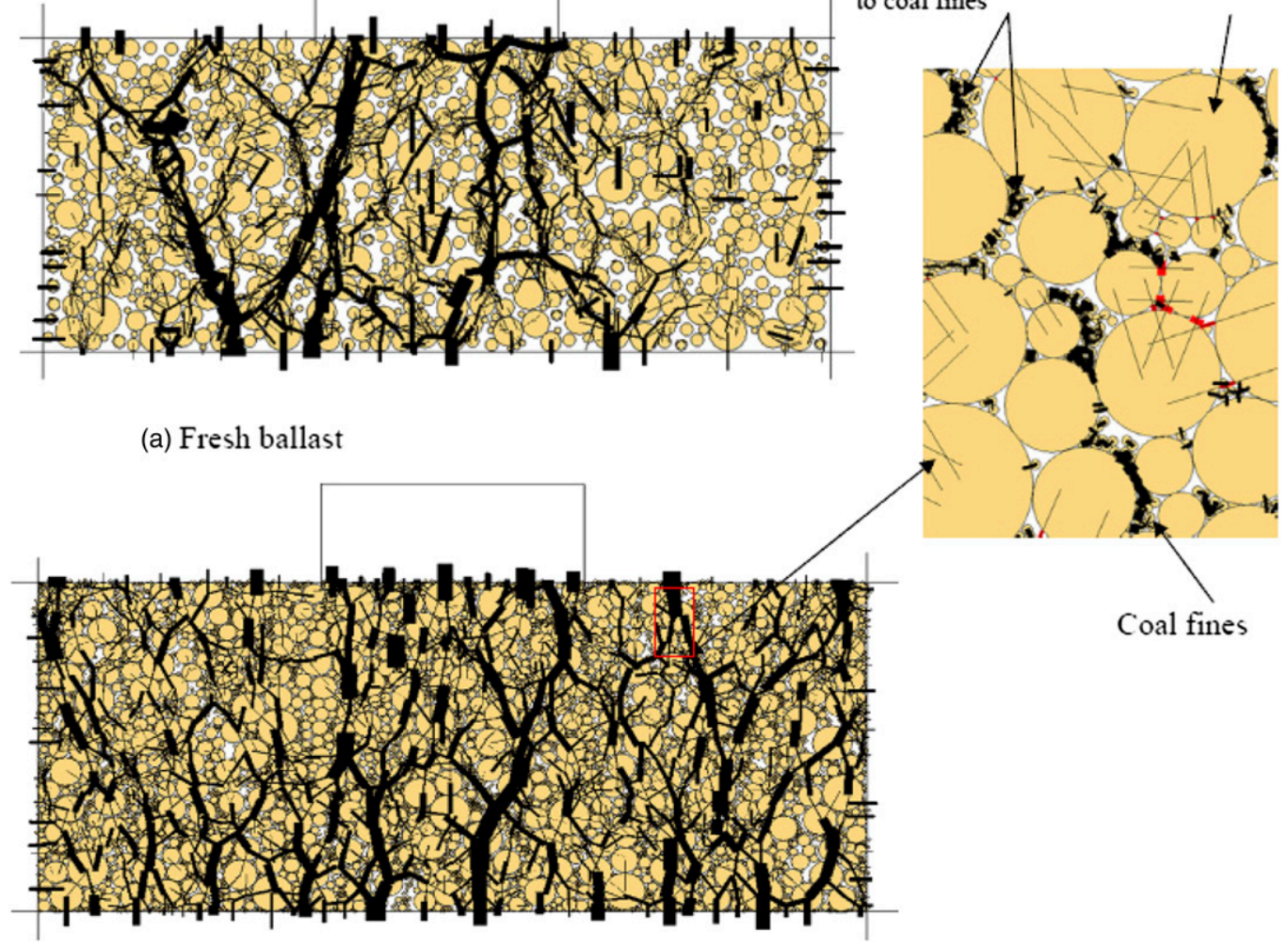

Coal fines

(b) $70 \%$ VCI-fouled ballast

Fig. 12. Contact force distributions of ballast at load cycle, $N=1000$ : (a) fresh ballast assembly; (b) $70 \%$ VCI fouled ballast assembly 
vertical and horizontal walls. Fig. 11 presents a comparison between the predicted and measured lateral displacement, settlement, and the number of broken bonds with load cycles. The DEM simulation sufficiently captured the deformation of fresh and fouled ballast subjected to cyclic loading, which approximately matched the measured data. DEM simulations also confirmed that the degree of fouling significantly affects ballast deformation. An increase in the VCI resulted in an increase in the lateral displacement of ballast, which leads to an increased settlement. In Fig. 11(c), the accumulated number of broken bonds decreased with an increase of the VCI, which supported the ballast breakage measured experimentally [Fig. 8(b)]. This observation is further justified by Fig. 12, which shows the distribution of contact forces of fresh and 70\% VCI fouled ballast. When fine particles accumulated in voids, the applied load was transferred more uniformly through the ballast skeleton, which distributed the contact forces in fouled ballast more uniformly than fresh ballast [Fig. 12(b)]. The contact forces transferred from grains of ballast through fine particles in the fouled ballast matrix mimic the cushioning effect of coal fines that effectively reduced the interparticle contact stresses.

\section{Conclusions}

A series of laboratory tests of fresh and fouled ballast at varying VCs with and without geogrid was conducted to investigate coal fouled ballast using a novel TPSA. This TPSA was designed to provide a more realistic simulation of Australian rail track conditions. The use of an air blower to foul the ballast was used, because it was a good method of simulating fouling that occurs in the field where coal fines gradually penetrate through the voids in the ballast from the surface. Based on the test results, all the samples showed a significant settlement within 100,000 cycles, followed by a gradual increase in settlement up to 300,000 cycles, and then remained relatively stable to the end. These results indicate that although the geogrid decreases the deformation of ballast because of the interlocking phenomenon occurring at the ballast geogrid interface, coal fines increasingly deform the ballast because of the lubricant effect, which facilitates sliding and rolling over each other. The geogrid produces the most benefit with fresh ballast (approximately 52 and 32\% reduction for lateral and vertical deformation, respectively), although this decreases considerably with an increase of the VCI (e.g., 12 and 5\% reduction for lateral and vertical deformation for $\mathrm{VCI}=40 \%$, respectively). Based on these findings, a threshold value of a VCI of $40 \%$ was proposed to assist practicing engineers in specifying a track maintenance schedule. Compared with fresh ballast, fouled ballast showed a higher dilation and at a relatively high level of coal fouling; the fouled ballast showed reduced particle breakage attributed to cushioning effect of coal fines.

Through better locking at the ballast geogrid interface, the inclusion of geogrid decreased the maximum pressure at the ballast layer, which helped decrease the breakage of ballast. The geogrid was more effective at reducing the breakage of ballast when the VCI was equal to or less than a threshold value of $\mathrm{VCI}=40 \%$, beyond that, its effect was minimal. Based on data measured from the TPSA, a novel equation was proposed to predict ballast settlement while considering the level of fouling. A DEM was also conducted to study the deformation and degradation of fresh and fouled ballast subjected to cyclic loading. For a given VCI, the DEM was able to capture the deformation of ballast in a similar way as those measured experimentally. The simulations indicated that although the deformation of a fouled ballast assembly increased with an increase of the VCI, the number of broken bonds in the assembly decreased with an increased VCI that was attributed to the cushioning effect of fine grains lubricating the surfaces of the ballast and decreasing the contact forces.

\section{Acknowledgments}

The authors are grateful for the financial support provided by the Cooperative Research Centre for Rail Innovation. The authors also thank Jayan Sylaja Vinod for his helpful discussions and guidance on DEM simulation. Laboratory assistance from Alan Grant and Ian Bridge is also very much appreciated.

\section{Notation}

The following symbols are used in this paper:

$a=$ empirical coefficient;

$b=$ empirical coefficient;

$e_{b}=$ void ratio of fresh ballast;

$e_{f}=$ void ratio of fouling material;

$G_{s b}=$ specific gravity of ballast;

$G_{s f}=$ specific gravity of fouling material;

$k_{n}=$ contact normal stiffness;

$k_{s}=$ contact shear stiffness;

$M_{b}=$ dry mass of fresh ballast;

$M_{f}=$ dry mass of fouling material;

$N=$ number of load cycles;

$R=$ ballast deformation factor;

$S=$ vertical settlement;

$S_{2}=$ lateral displacement (perpendicular to the sleeper);

$S_{3}=$ lateral displacement (parallel to the sleeper);

$\left(\varepsilon_{s}\right)_{\mathrm{avg}}=$ average shear strain;

$\left(\varepsilon_{v}\right)_{\text {avg }}=$ average volumetric strain;

$\left(\varepsilon_{1}\right)_{\text {avg }}=$ average vertical strain (major principal strain) in the ballast layer;

$\left(\varepsilon_{2}\right)_{\mathrm{avg}}=$ average intermediate principal strain in the ballast layer (perpendicular to the sleeper);

$\left(\varepsilon_{3}\right)_{\text {avg }}=$ average lateral strain (minor principal strain) parallel to a sleeper;

$\mu=$ interparticle coefficient of friction;

$\sigma_{2}=$ confining pressure perpendicular to the sleeper; and

$\sigma_{3}=$ confining pressure in parallel to the sleeper.

\section{References}

Atalar, C., Das, B. M., Shin, E. C., and Kim, D. H. (2001). "Settlement of geogrid-reinforced railroad led to failure due to cyclic load." Proc. 15th Int. Conf. Soil Mech. Geotech. Eng., 3, 2045-2048.

Australian Standard. (1996). "Aggregates and rock for engineering purposes; Part 7: Railway ballast." AS 2758.7 Sydney, Australia.

Bathurst, R. J., and Raymond, G. P. (1987). "Geogrid reinforcement of ballasted track." Transportation Research Record 1153, Transportation Research Record, Washington, DC.

Brown, S. F., Kwan, J., and Thom, N. H. (2007). "Identifying the key parameters that influence geogrid reinforcement of railway ballast." J. Geotext. Geomembr., 25(6), 326-335.

Brown, S. F., Thom, N. H., and Kwan, J. (2006). "Optimising the geogrid reinforcement of rail track ballast." Railway Foundations: Proc., Railfound 06, Univ. of Birmingham, Birmingham, UK, 346-354.

Budiono, D. S., McSweeney, T., Dhanasekar, M., and Gurung, N. (2004). "The effect of coal dust fouling on the cyclic behaviour of railtrack ballast." Cyclic behaviour of soils and liquefaction phenomena, Taylor \& Francis, London, 627-632. 
Cundall, P. A., and Strack, O. D. L. (1979). "A discrete numerical model for granular assemblies." Geotechnique, 29(1), 47-65.

Dombrow, W., Huang, H., and Tutumluer, E. (2009). "Comparison of coal dust fouled railroad ballast behavior-Granite vs. limestone." Proc., 8th Int. Conf. Bearing Capacity of Roads, Railways and Airfields, Taylor \& Francis, London, 1349-1357.

Esveld, C. (2001). Modern railway track, MRT Press, Albert Heijn Zaltbommel, Zaltbommel, Netherlands.

Feldman, F., and Nissen, D. (2002). "Alternative testing method for the measurement of ballast fouling." Conf. Railway Eng., Railway Technical Society of Australasia, Wollongong, Australia, 101-111.

Fernandes, G., Palmeira, E. M., and Gomes, R. C. (2008). "Performance of geosynthetic-reinforced alternative sub-ballast material in a railway track." Geosynth. Int., 15(5), 311-321.

Göbel, C. H., Weisemann, U. C., and Kirschner, R. A. (1994). "Effectiveness of a reinforcing geogrid in a railway subbase under dynamic loads." J. Geotext. Geomembr., 13(2), 91-99.

Han, X., and Selig, E. T. (1997). "Effects of fouling on ballast settlement." Proc., 6th Int. Heavy Haul Conf., IHHA Press, Cape Town, South Africa, 257-268.

Hossain, Z., Indraratna, B., Darve, F., and Thakur, P. K. (2007). "DEM analysis of angular ballast breakage under cyclic loading." Geomech. Geoeng., 2(3), 175-181.

Huang, H., and Tutumluer, E. (2011). "Discrete element modeling for fouled railroad ballast." Construct. Build. Mater., 25(8), 3306-3312.

Huang, H., Tutumluer, E. and Dombrow, W. (2009a). "Laboratory characterization of fouled railroad ballast behavior." Transportation Research Record 2117, Transportation Research Board, Washington, DC.

Huang, H., Tutumluer, E., Hashash, Y. M. A., and Ghaboussi, J. (2009b). "Discrete element modeling of aggregate behavior in fouled railroad ballast." Geotechnical Special Publication No. 192, ASCE, Reston, VA, 33-41.

Indraratna, B., Khabbaz, H., Salim, W., and Christie, D. (2006). "Geotechnical properties of ballast and the role of geosynthetics in rail track stabilisation." J. Ground Improve., 10(3), 91-102.

Indraratna, B., Lackenby, J., and Christie, D. (2005). "Effect of confining pressure on the degradation of ballast under cyclic loading." Geotechnique, 55(4), 325-328.

Indraratna, B., Ngo, N. T., and Rujikiatkamjorn, C. (2011a). "Behavior of geogrid-reinforced ballast under various levels of fouling." J. Geotext. Geomembr., 29(3), 313-322.

Indraratna, B., and Salim, W. (2003). "Deformation and degradation mechanics of recycled ballast stabilised with geosynthetics." J. Soils Found., 43(4), 35-46.

Indraratna, B., Salim, W., and Christie, D. (2002). "Perfomance of recycled ballast stabilised with geosynthetics." Conf. Railway Eng., Railway Technical Society of Australasia, Wollongong, Australia, 113-120.

Indraratna, B., Salim, W. and Rujikiatkamjorn, C. (2011b). Advanced rail geotechnology-Ballasted track, CRC Press, London.

Indraratna, B., Thakur, P. K., and Vinod, J. S. (2010). "Experimental and numerical study of railway ballast behaviour under cyclic loading." Int. J. Geomech., 10(4), 136-144.

Itasca. (2003). Particle flow code in two and three dimensions, Itasca Consulting Group, Minneapolis, MN.
Konietzky, H., te Kamp, L., and Groeger, T. (2004). "Use of DEM to model the interlocking effect of geogrids under static and cyclic loading." Numerical modeling in micromechnics via particle methods, Taylor \& Francis, London, 3-11.

LabVIEW 10.0 [Computer software]. North Ryde, NSW, Australia, National Instruments.

Lackenby, J., Indraratna, B., McDowell, G. R., and Christie, D. (2007). "Effect of confining pressure on ballast degradation and deformation under cyclic triaxial loading." Geotechnique, 57(6), 527-536.

Le Pen, L. (2008). "Track behaviour: The importance of the sleeper to ballast interface." Ph.D. thesis, Univ. of Southampton, Southampton, U.K.

Lim, W. L., and McDowell, G. R. (2005). "Discrete element modelling of railway ballast." Granul. Matter, 7(1), 19-29.

Lobo-Guerrero, S., and Vallejo, L. E. (2005). "Discrete element method evaluation of granular crushing under direct shear test condition." J. Geotech. Geoenviron. Eng., 131(10), 1295-1300.

Lu, M., and McDowell, G. R. (2006). "Discrete element modelling of ballast abrasion." Geotechnique, 56(9), 651-655.

Lu, M., and McDowell, G. R. (2008). "Discrete element modelling of railway ballast under triaxial conditions." Geomech. Geoeng., 3(4), 257-270.

Lu, M., and McDowell, G. R. (2010). "Discrete element modelling of railway ballast under monotonic and cyclic triaxial loading." Geotechnique, 60(6), 459-467.

McDowell, G. R., Harireche, O., Konietzky, H., Brown, S. F., and Thom, N. H. (2006). "Discrete element modelling of geogrid-reinforced aggregates." Proc., ICE Geotech. Eng., 159(1), 35-48.

Palmeira, E. M. (2009). "Soil-geosynthetic interaction: Modelling and analysis." J. Geotext. Geomembr., 27(5), 368-390.

Qian, Y., Han, J., Pokharel, S. K., and Parsons, R. L. (2010). "Experimental study on triaxial geogrid-reinforced bases over weak subgrade under cyclic loading." GeoFlorida 2010: Advances in Analysis, Modeling and Design (Geotechnical Special Publication 199), ASCE, Reston, VA, 1208-1216.

Raymond, G., and Ismail, I. (2003). "The effect of geogrid reinforcement on unbound aggregates." J. Geotext. Geomembr., 21(6), 355-380.

Raymond, G. P. (2002). "Reinforced ballast behaviour subjected to repeated load." J. Geotext. Geomembr., 20(1), 39-61.

Raymond, G. P., and Bathurst, R. J. (1994). "Repeated-load response of aggregates in relation to track quality index." Can. Geotech. J., 31(4), 547-554.

Selig, E. T., and Waters, J. M. (1994). Track geotechnology and substructure management, Thomas Telford, London.

Shenton, M. J. (1975). "Deformation of railway ballast under repeated loading conditions." Proc., Railroad Track Mech. Tech., M. Kerr, ed., Princeton Univ., 387-404.

Shin, E. C., Kim, D. H., and Das, B. M. (2002). "Geogrid-reinforced railroad bed settlement due to cyclic load." Geotech. Geol. Eng., 20(3), 261-271.

Shukla, S. K. and Yin, J. (2006). Fundamentals of geosynthetics engineering, Taylor \& Francis, London.

Timoshenko, S. P., and Goodier, J. N. (1970). Theory of elasticity, McGraw Hill, New York.

Tutumluer, E., Dombrow, W., and Huang, H. (2008). "Laboratory characterization of coal dust fouled ballast behavior." AREMA 2008 Annual Conf. and Exposition, AREMA Press, Chicago. 